\title{
An exploration of barriers for commercializing phosphorus recovery technologies
}

Li, Bing; Udugama, Isuru A.; Mansouri, Seyed Soheil; Yu, Wei; Baroutian, Saeid; Gernaey, Krist V.; Young, Brent R.

Published in:

Journal of Cleaner Production

Link to article, DOI:

10.1016/j.jclepro.2019.05.042

Publication date:

2019

Document Version

Peer reviewed version

Link back to DTU Orbit

Citation (APA):

Li, B., Udugama, I. A., Mansouri, S. S., Yu, W., Baroutian, S., Gernaey, K. V., \& Young, B. R. (2019). An exploration of barriers for commercializing phosphorus recovery technologies. Journal of Cleaner Production, 229, 1342-1354. https://doi.org/10.1016/j.jclepro.2019.05.042

\section{General rights}

Copyright and moral rights for the publications made accessible in the public portal are retained by the authors and/or other copyright owners and it is a condition of accessing publications that users recognise and abide by the legal requirements associated with these rights.

- Users may download and print one copy of any publication from the public portal for the purpose of private study or research.

- You may not further distribute the material or use it for any profit-making activity or commercial gain

- You may freely distribute the URL identifying the publication in the public portal

If you believe that this document breaches copyright please contact us providing details, and we will remove access to the work immediately and investigate your claim 

Phosphorous Recovery Technologies

Bing Li ${ }^{a, c}$, Isuru A. Udugama ${ }^{b}$, Seyed Soheil Mansouri ${ }^{b}$, Wei Yu ${ }^{a}$, Saeid Baroutian ${ }^{a}$, Krist V. Gernaey $^{b}$, Brent R. Young ${ }^{a}$

a: Department of Chemical \& Materials Engineering, Faculty of Engineering, The University of Auckland, Private Bag 92019, Auckland, New Zealand

${ }^{b}$ : Department of Chemical and Biochemical Engineering, Technical University of Denmark, Sфltofts Plads, Building 229, DK-2800 Kongens Lyngby, Denmark

c: State Key Laboratory of Hydro Science and Engineering, Department of Hydraulic Engineering, Tsinghua University, Beijing, China

\begin{abstract}
Phosphorous is an essential element in sustaining modern day farming practices and is expected to deplete within the next 100 years. However, phosphorous utilisation efficiency in most countries is below 20\%, making the implementation of suitable phosphorous recovery technologies urgent and necessary. In spite of intensive research and development, there are only a few commercial recovery facilities being implemented. Therefore, there is a need to identify potential roadblocks/hurdles in a systematic manner. To this end, technology readiness level, process economic and sensitivity analyses were novelly integrated and employed to assess the opportunities and hurdles during the implementation of current phosphorous recovery technologies. The enhanced feasibility assessment methodology is demonstrated via a case study, revealing that only struvite crystallization is sufficiently mature to be industrially implemented. Under most scenarios evaluated, struvite crystallization can be profitable or break-even if financial assistance is provided from policymakers. Sensitivity analysis showed that overall profitability is highly sensitive to raw materials cost and product sale price, while phosphorous concentration in waste streams has less effect. Such an assessment could be extended to identify barriers in other resource recovery technologies.
\end{abstract}

Keywords: Phosphorous recovery; Struvite crystallization; Technical readiness level; Net present value; Sensitivity analysis 


\section{Introduction}

Phosphorous (P) is an essential macro-nutrient for cells, crops, living animals and human beings. Nearly all phosphorous being used is sourced from industrial phosphate rock. In 2017, nearly 70 million tons of phosphate rock ( $\mathrm{P}_{2} \mathrm{O}_{5}$ equivalent) were consumed, while the total resource is predicted to deplete within the next 100 years (Elser et al., 2011; Li et al., 2018). However, phosphorous utilisation efficiency in most countries is below 20\% (Li et al., 2015), meaning more than $80 \%$ losses. Such significant losses increase the phosphorous concentration in local streams, and cause environmental problems such as eutrophication and red tide. What is more, the world's population is to increase to 9 billion by 2050 (Samir et al., 2017), meaning additional food requirements, and therefore additional phosphorous is required. Phosphorous recovery provides an opportunity to minimise the environmental impact and to reduce the amount of phosphate rock mined. It has therefore drawn significant attention over the past two decades.

To date, more than 30 phosphorous recovery technologies have been investigated (Cieślik et al., 2017), most of which have been triggered by environmental restrictions (sustainability and resource efficiency), concerns regarding the finite and geopolitical considerations surrounding phosphate deposits, and the increase of phosphate rock price. An ideal phosphorous recovery technology would feature a high recovery rate, low capital and operational cost and useful by-product with less environmental risks (Egle et al., 2015). However, most previous studies focus on the reaction mechanisms (Li et al., 2016; Zamora et al., 2016; Huang et al., 2018), while some of them are economically unjustified or designed in a way that cannot be easily implemented (Egle et al., 2015). This makes the application of recovery technologies in a given stream complicated, not only because of the differences in process layouts and requirements, but also the variations in waste volume, phosphorous concentrations, phosphorous forms (for example, chemically, orthophosphate or organically bonded) and interfering components (for example heavy metals, organics and pathogens).

Therefore, an assessment framework to identify potential roadblocks/hurdles for the commercialization of phosphorous recovery becomes necessary. Azapagic et al. (2016) introduced a sustainable production and consumption framework named DESIRES, where the economics, environmental and social sustainability criteria were applied to evaluate the efficiency of electricity generation in the United Kingdom. Tura et al. (2019) applied a multiple-case study approach including environmental, economic, social, political and institutional, technological and informational, supply chain, and organizational factors to identify the drivers and barriers for developing new business in circular economy. Similar criteria were also used by Luthra et al. (2017) for supply chains. Udugama et al. (2017) and Mansouri et al. (2017) discussed the techno-economic considerations of resource recovery from bio-based processes, as well as the specific challenges and

\begin{tabular}{|l|}
\hline Formateret: Sænket skrift \\
\hline Formateret: Sænket skrift \\
\hline Flyttet (indsættelse) [2] \\
\hline Slettet: , which is predicted \\
\hline
\end{tabular}

Flyttet opad [2]: However, phosphorous utilisation efficiency in most countries is below 20\% (Li et al., 2015), meaning more than 80 losses. Such significant losses increase the phosphorous concentration in local streams, and cause environmental problems such as eutrophication and red tide. 
opportunities. While evaluation criteria in those works apply in some degree to phosphorous recovery, key aspects such as variations in waste streams, the influence of pre-treatment processes and identification of control variables for performance improvement and cost reduction are different. What is more, the large number of available technologies (over 30 for phosphorous recovery technologies) make the data collection and selection of a suitable technology time-consuming. Xia et al. (2019) established a comprehensive barrier identification system for green technology adoption. However, lack of data in phosphorous recovery operational stage also make the operational level assessment difficult.

In this study, we define phosphorous recovery technologies as processes that recover bioactive phosphate with contaminates (e.g. trace element, organics) satisfying legal requirements. Although regulations vary across different regions, processes with well-known negative environment effect in the literature are ignored. For example, direct application of sewage sludge onto agricultural land is not considered due to the existence of organic contaminants, heavy metals and pathogens, At the same time, phosphorous enrichment (for example, absorption and the traditional Enhanced Biological Phosphorous Removal Process) and phosphorous release (for example, thermal hydrolysis, microwave treatment and supercritical water extraction) processes are excluded. With these limitations in mind and the multi-faceted considerations required, a new technology assessment framework considering technology readiness level (TRL) assessment, process economics and sensitivity analyses are proposed (Section 2). This framework differs from previous research as it extends traditional TRL assessment to a two-step system based on expert knowledge and widely available literature, and introduces the design of experiments for sensitivity analysis in an evaluation framework. The framework was then applied to a case study, where the applicability of the framework and barriers for current commercialisation of phosphorous recovery technologies were discussed. The development framework can be used to direct scientific research, formulating industrial policy and assisting investments in the future.

\section{Methodology}

A systematic, hierarchical methodology was developed, taking into account decision gates of waste stream characterisation, technology readiness level and economic analysis. The proposed methodology has an enhanced Technology Readiness Level (TRL) step and has also incorporated a sensitivity analysis to identify key operating parameters, and to investigate the influence of market and economic variations on the process profitability. Figure 1 is an overview of the framework, which was illustrated using information from the Oxley WWTP in Queensland, Australia (Shu et al., 2006) as a case study. This plant is a conventional BOD-removal activated sludge plant with an average dry weather flow rate of 550,000 $\mathrm{M}^{3} / \mathrm{day}$, which contains 4-14 mg/ $\mathrm{PO}_{4}{ }^{3-}$ phosphorous (Münch et al., 2001).

\section{Flyttet (indsættelse) [3]}

Slettet: $\mathbb{I}$

Flyttet opad [3]: What is more, the large number of available technologies (over 30 for phosphorous recovery technologies) make the data collection and selection of a suitable technology timeconsuming. II

Slettet: phosphorous

Flyttet (indsættelse) [1]

Slettet: Direct

Slettet: , as

Slettet:

Slettet: are strictly restricted by legal regulations

Slettet: in the form of safe products that can be directly reused. Therefore,

Flyttet opad [1]: Direct application of sewage sludge onto agricultural land is not considered, as the existence of organic contaminants, heavy metals and pathogens are strictly restricted by legal regulations. 


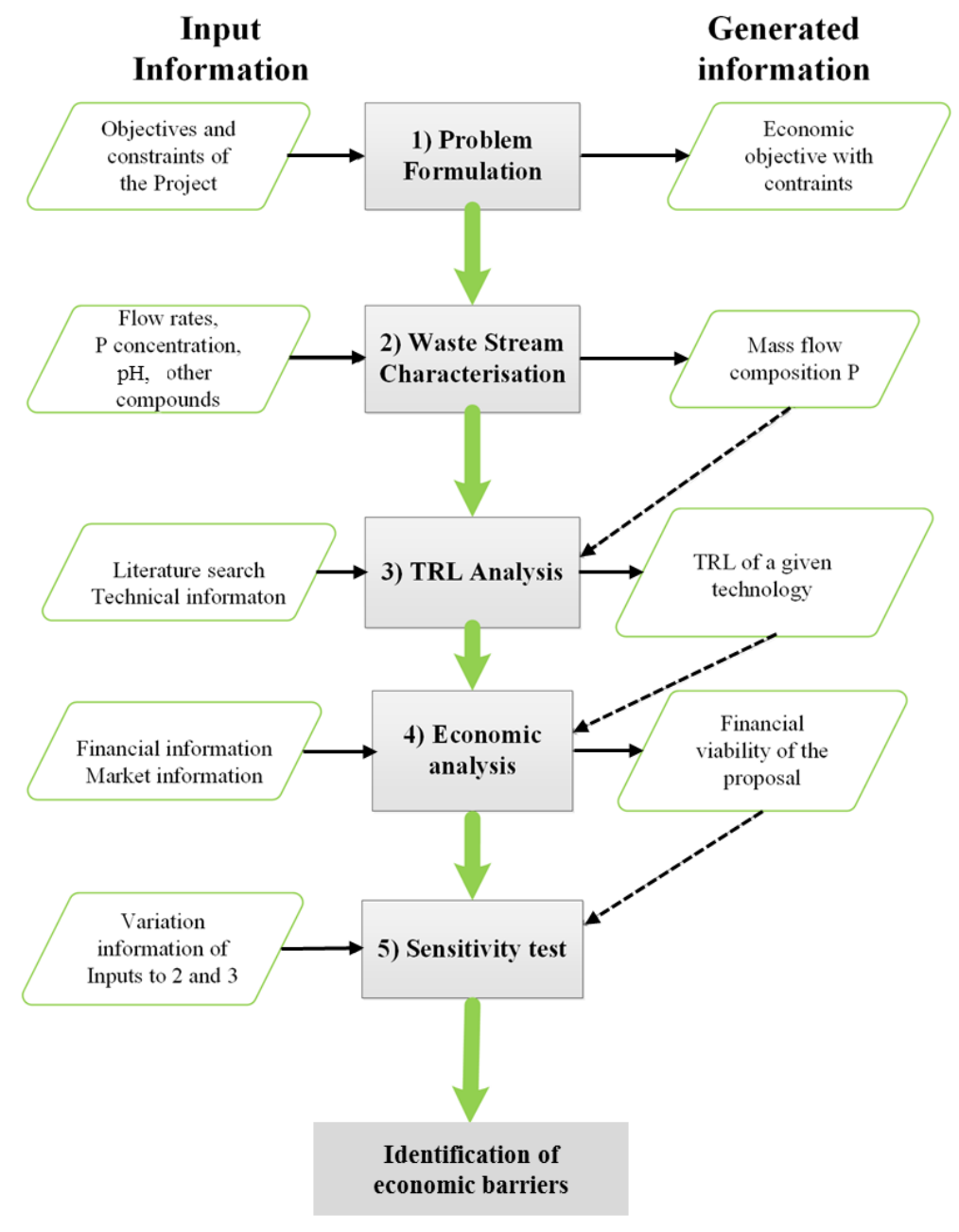

Figure 1: Proposed enhanced hierarchical techno-economic methodology for efficiently assessing the barriers to commercialising P-recovery technologies

\subsection{Step 1: Problem Formulation}

132 Equation 1 describes the objective function (objective) of this framework and the constraints,

$$
\max N P V_{\text {F.C.F }}\left(\text { P.recovery }_{\cdot \text { Technology }}, \text { Conditions }_{\text {Steam }}\right. \text { ) }
$$

Subject to P.recovery.Technology $\geq \min$ TRL

The objective of this framework is to identify P recovery technology (P.rec.Technology $)$ that gives 
(Conditions Steam ), which is subjected to the constraints of a minimum Technology Readiness Level $(\min T R L)$ that is practically feasible for implementation.

\subsection{Step 2: Waste Stream Characterisation}

In a given waste stream, volume/ mass flow rate, elemental concentrations together with the total amount of phosphorous available need to be quantified. This information makes the first stop/go decision by the user. If the available mass of phosphorous is deemed too low by the user, the stream will not be suitable for phosphorous recovery.

\subsection{Step 3: Technical Readiness Level (TRL)}

Technology screening of a given stream not only depends on its capabilities, but also on the level of technology maturity (Rybicka et al., 2016). This is of relevance to many technology development projects as significant work needs to be carried out to transition a technology that has been demonstrated at lab scale to a commercial product. Technology maturity can also be used to put into perspective the additional risks (both economically and operationally) a project takes on, when installing a novel technology that is still under development. To standardise this decision making process, concepts such as Technology readiness level (TRL) have been developed.Technology readiness level (TRL) is amatrix that was originally developed by NASA to assess space technologies and since has found wide spread use in other areas of technology development (Rybicka et al., 2016). Equipped with the TRL matrix, the state of development of a given technology can be determined and an informed decision can be made about the operational and economic risks that a given technology may bring to a project. The information gained through the application of TRL matrix is also compatible and complimentary to the management based approach of innovation lifecycle that is a used to understand new technology development in social sciences and business management $($ (xxx).. However, the TRL matrix in comparison to innovation lifecycle takes a more technical approach in its analysis. In the context of phosphorous recovery, TRL can be employed systematically to compare the technology maturity of different phosphorous recovery technologies and make an informed decision about the current level of maturity of these technologies and what risks it may bring to a phosphorous recovery project. Detailed definitions of TRLs are listed in Table 1 (Modified from Parasuraman, 2000).

Table 1: Definition of different TRLs

\begin{tabular}{cl}
\hline TRL & State of Development \\
\hline 1 & Basic principle observed and reported \\
2 & Technology concept / application formulated \\
3 & Analytical and experimental critical function / Characteristic proof - of - concept \\
4 & Component and / or breadboard validation in lab \\
5 & Component and / or breadboard validation in relevant environment \\
6 & System/subsystem model or prototype demonstration in relevant environment \\
7 & System prototype demonstration in relevant environment
\end{tabular}

TRL State of Development

Basic principle observed and reported

Component and / or breadboard validation in lab

System/subsystem model or prototype demonstration in relevant environmen

System prototype demonstration in relevant environment
Slettet: and has resulted in the development of standardised matrices to understand the status of technology maturity. T Slettet: one such

Slettet: to assess the maturity of a technology Slettet: (

Kommenterede [ISU1]: 10.1016/..sbspro.2016.05.527 10.1016/i.techfore.2018.07.045 
8 Actual system completed and qualified through demonstration

9 Actual system proven through successful mission operations working on attaining a proof of concept. documented. such as a waste water treatment plant. ambiguity of this judgement.

Table 2: Deciding the final TRL
To categorize TRL, a TRL range was firstly assigned based on the number of occurrences in literature. A thorough literature review is necessary. It helps to understand where information is available, and where it is lacking. A guideline for this first assessment is based on Rybicka (2016);

- A TRL of 1-3 is assigned for technologies that only have lab scale application. Lab scale is defined as work conducted in a lab setting and at bench scale primarily

- A TRL of 4-6 is for a technology that has both lab and pilot scale applications. Pilot scale is defined as work that was conducted on developing a robust process (either in a lab or at pilot scale) and the concept is proven and mechanisms are well

- A TRL of 7-9 is for technologies that are at full-scale application, which is defined as the implementation of a phosphorous recovery technology at an industrial site

In order to further refine these TRL ranges to a single TRL score, the authors propose the following factors should be considered: process awareness, technical 'knowhow' and number of applications in each category (e.g. lab, pilot and full scale), in literature at a given TRL range. The numbers of occurrences of applications will be considered at a high level if there are over five applications recorded, a medium level for one to five records and low when no application is found. Process awareness will be at a high level if the reaction/separation mechanisms are completely understood, a medium level if reaction mechanisms are somewhat known and at a low level if few reaction mechanisms are reported. A high technical 'knowhow' is based on well-established subtechnologies, such as traditional membranes or composting. If the basis of the sub-technologies used is recent developments with several pilot/full-scale demonstration plants, a medium level will be assigned. A low technical 'knowhow' level will be assigned if a technology is novel. The abovementioned levels for different factors will be used to determine a TRL score based on its corresponding TRL range (shown in Table 2). The addition of this second level of refinement allows an interested user to easily assess the final TRL of a given technology while reducing the

\begin{tabular}{ccccc}
\hline $\begin{array}{c}\text { TRL } \\
\text { range }\end{array}$ & Process awareness & $\begin{array}{c}\text { Technical } \\
\text { 'knowhow' }\end{array}$ & $\begin{array}{c}\text { Number of } \\
\text { applications }\end{array}$ & $\begin{array}{c}\text { TRL } \\
\text { score }\end{array}$ \\
\hline $1-3$ & Low & Low & Low & 1
\end{tabular}

\section{Slettet: Guidelines}

Slettet: laid out by

Slettet: were used
Slettet: These above TRL ranges are further refined to TRL scores based on three factors:

Slettet: application Slettet: $\mathrm{s}$ 


\begin{tabular}{ccccc} 
& Low to medium & Medium & Low & 2 \\
& Medium & Medium & Low & 3 \\
\hline \multirow{3}{*}{$4-6$} & Medium & Low & Low & 4 \\
& High & Medium & Medium & 5 \\
& High & At least one factor is High & 6 \\
\hline \multirow{3}{*}{$7-9$} & High & Low & High & 7 \\
& High & Medium & Medium & 8 \\
& High & At least one factor is high & 9 \\
\hline
\end{tabular}

214 The stop/go criterion in this step is the identification of an applicable process technology that is of a

sufficient TRL. In the context of this work, the authors would define TRL 7 or above as sufficient, as technologies at these TRL's have been tested at industrial scale.

\subsection{Step 4: Economic Analysis}

Even with a high TRL score, a technology can be infeasible if the cost of raw material, utilities and maintenance are higher than revenues derived. In the context of phosphorous recovery, process costs $\left(\right.$ Cost $\left._{p, \text { recovery }}\right)$ are from chemical dosage (assessed based on stoichiometry), product refining, energy, maintenance and staff salary, while the revenue (Revenue $p_{\text {, recovery }}$ ) is affected by phosphorous concentrating ratio, struvite recovery efficiency and product sale price (shown in Equation 2). Capital investments such as land purchase and equipment cost have been ignored due to their significant variation across different regions.

$$
\text { Net Income }=\text { Revenue }_{\text {P.recovery }}-\text { Cost }_{\text {P.recovery }}
$$

The net present value (NPV) is used in capital budgeting to analyze the profitability of a projected investment. A positive value reflects the project is self-sustainable. It is a function of annual net income, discount rate $(r)$ and project payback period $(n)$. In this analysis, we will only analyze the Present Value (PV) of future cash flows as this value can be used to make decisions of a project's viability and compare different operating and economic regimes without the need to carryout complicated and often erroneous capital investment calculations

$$
P V=\text { net income }\left(1-\frac{1}{(1+r)^{n}}\right) / r
$$

\subsection{Step 5: Sensitivity Analysis}

Sensitivity analysis is an essential step to identify key barriers for the commercialisation of phosphorous recovery technologies. Design of experiments (DoE) greatly reduces the number of test runs without sacrificing information on the main effects. Therefore, a $2^{\text {nd }}$ order factor interaction function in DoE are used to investigate what main factors make phosphorous recovery infeasible. QQ plots are used to compare distributions between designed conditions and the $2^{\text {nd }}$ order function model. Analysis of variance (ANOVA) is applied to identify sources of variation. Factor values with a $p$-value below 0.05 were considered to be significant (Ye et al., 2010). To show the validity of fit of the polynomial functions, the co-efficient of determination $\left(\mathrm{R}^{2}\right)$ and the 
242 adjusted co-efficient ( $\mathrm{R}^{2} \mathrm{adj}$ )were used. $\mathrm{R}^{2}$ illustrates how much of the observed variability in the 243 data is explained by the model. $\mathrm{R}^{2}$ adj modifies $\mathrm{R}^{2}$ by considering the number of predictors in the 244 model. Based on the above, the influence of variations in waste stream compositions, market,

\subsection{Step 1: Problem Formulation}

The case study is to find the maximum Present Value (NPV) of future cash flows that can be generated by a phosphorous recovery technology for the Oxley WWTP, using technologies that have a TRL of 7 or above.

\subsection{Step 2: Stream characterisation}

Conditions used in the case study are documented in Section 3.4.

\subsection{Step 3: Technology search and TRL analysis}

A thorough literature review was conducted using the Web of Science database. While we acknowledge this is not an exhaustive literature survey, it is a comprehensive one, with over 945 papers analysed, and the relative number of papers indicates levels of process awareness, technical 'knowhow' and occurrence of full-scale applications. A general conclusion regarding the technology readiness of current state of art technologies was then drawn. Techniques and processes with potential for full-scale implementations or which are already implemented are summarised in Table 3.
Slettet: , shown by Eqns. (4) and (5) respectively,

$$
\begin{aligned}
& \text { Slettet: } \mathbb{I} \\
& R^{2}=1-\frac{S S_{\text {residual }}}{S S_{\text {mod } e l}+S S_{\text {residual }}} \\
& R_{\text {adj }}^{2}=1-\frac{n-1}{n-m}\left(1-R^{2}\right)
\end{aligned}
$$


Table 3: Overview of current $\mathrm{P}$ recovery processes and technologies

\begin{tabular}{|c|c|c|c|c|c|c|}
\hline Process & Advantages & Disadvantages & Technology & Product & Source & Reference \\
\hline \multirow[t]{2}{*}{ Composting(C) } & \multirow{2}{*}{$\begin{array}{l}\text { Low Cost } \\
\text { Onsite Recovery }\end{array}$} & \multirow{2}{*}{$\begin{array}{l}\text { - Long stabilization time } \\
\text { - Contamination }\end{array}$} & $\begin{array}{l}\text { Traditional } \\
\text { composting }\end{array}$ & A & OW & Cieślik et al., 2017 \\
\hline & & & Vermicomposting & A & OW & Cieślik et al., 2017 \\
\hline \multirow{5}{*}{$\begin{array}{l}\text { Struvite } \\
\text { Crystallization } \\
\text { (S) }\end{array}$} & \multirow{5}{*}{$\begin{array}{l}\text { Slow release fertilizer } \\
\text { Reduces sludge volume } \\
\text { Reduces nutrient load }\end{array}$} & \multirow{5}{*}{$\begin{array}{l}\text { - Increases capital cost } \\
\text { Economics unclear }\end{array}$} & AirPrex® & $\mathrm{B}$ & DSL & Kataki et al., 2016 \\
\hline & & & NuResys ${ }^{\circledR}$ & $\mathrm{B}$ & DS & $\begin{array}{l}\text { Schoumans et al., } \\
2015\end{array}$ \\
\hline & & & Ostara ${ }^{\circledR}$ & $\mathrm{B}$ & DS & Cieślik et al., 2017 \\
\hline & & & Phospaq ${ }^{\circledR}$ & B & DS & Egle et al., 2015 \\
\hline & & & STRUVIA & $\mathrm{B}$ & Ds & Egle et al., 2015 \\
\hline $\begin{array}{l}\text { Biomineralization } \\
\text { (B) }\end{array}$ & - Little Mg required & - Long stabilization time & 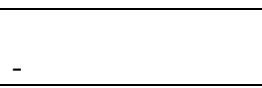 & B & Urine & Simoes et al., 2017 \\
\hline \multirow{2}{*}{ Incineration (I) } & \multirow{2}{*}{$\begin{array}{l}\text { - High efficiency } \\
\text { - Reduces waste volume }\end{array}$} & - High capital cost & - & $\mathrm{C}$ & SS & Cieslik et al., 2014 \\
\hline & & - High energy cost & - & $\mathrm{C}$ & SS & Egle et al., 2015 \\
\hline \multirow{3}{*}{ Calcium P (CP) } & \multirow{3}{*}{$\begin{array}{l}\text { Low Cost } \\
\text { Implemented easily } \\
\text { Onsite Recovery }\end{array}$} & \multirow{3}{*}{ - Limited application } & Filter substrate & $\mathrm{D}$ & SA & $\begin{array}{l}\text { Loganathan et al., } \\
2014\end{array}$ \\
\hline & & & RecoPhos® & $\mathrm{D}$ & SA & Arnout et al., 2016 \\
\hline & & & LOTUS & $\mathrm{D}$ & SA & Egle et al., 2015 \\
\hline \multirow{2}{*}{ Gasification (G) } & - High efficiency & - High capital cost & Thermphos® & $\mathrm{E}$ & SA & Ribarova et al., 2017 \\
\hline & - produces pure $\mathrm{P}$ element & - High energy cost & InduCarb® & $\mathrm{E}$ & SA & Arnout et al., 2016 \\
\hline
\end{tabular}

: Composted Biomass, B: Struvite, C: Incinerated Ash, D: Calcium P, E: Pure P

OW: Organic Waste, DSL: Digested Sludge, DS: Digester Supernatant, SS: Sewage Sludge, SA: Sludge Ash 


\subsubsection{Current State of P-recovery technologies}

Composting is a traditional worldwide biomass/waste management process using microorganisms or earthworms to break down green waste (leaves, food waste, and animal waste) into humus after weeks or months. Modern, methodical composting is a multi-step, closely monitored process with measured inputs of water, air, and carbon- and nitrogen-rich materials. The composted solid waste is rich in phosphorous and other nutrients and could be either directly used as soil mixes or fertiliser after further treatment.

Struvite crystallization is a wastewater phosphorous recovery technology with the potential to ease both the scarcity of phosphorous rock resources and eutrophication. Recovered phosphorous could be applied to soil at rates greatly exceeding those of conventional fertilizers without burning plant roots (Kataki et al., 2016). This technology has been tested in various wastewater streams, reactors (Rahaman et al., 2014; Melia et al., 2017) and operating conditions (Kumar et al., 2015, de Luna et al., 2015). Combinations with pre-treatment and post-treatment processes have also been investigated.

Biomineralization is a potential phosphorous recovery technology that produces minerals in the presence of living organisms. Phosphorous is recovered in the form of struvite or hydroxyapatite. Biomineralized phosphate shows higher recycle potential with less external chemical addition (Soares et al., 2014) and allows more flexible influent composition (for example, phosphorous concentrations in the influent could be as low as $10 \mathrm{mg} / \mathrm{L}$ ). Myxococcus xanthus, Bacillus pumilus, Halobacterium salinarum and Brevibacterium antiquum have been tested for potential phosphorous recovery. Bacillus pumilus and B. antiquum are capable of growing and producing bio-minerals identified as struvite that reached up to $250 \mu \mathrm{m}$ in size within ten days (Li et al., 2017).

Incineration followed by chemical extraction produces calcium phosphate as a by-product. $\mathrm{HCl}$, $\mathrm{HNO}_{3}, \mathrm{H}_{2} \mathrm{SO}_{4}$, critic or oxalic acids have been intensively reported to extract phosphorous from incinerated ash. Such extraction is normally completed in 100 minutes with phosphorous, K, Ca, $\mathrm{Mg}$ and $\mathrm{S}$ as main ingredients. It has been proven that sulphuric acid extraction ends up with the least amount of heavy metal, due to fewer complexation reactions when compared with other acids (Egle, et al., 2015). Nakakuno (Nakakuno et al., 2012) reported that caustic soda could be used to remove heavy metals from the extraction process, however, the process efficiency reaches only $40 \%$. Phosphorous in sludge ash could also be recovered similarly, which was proven by ICL Fertilizers (Egle, et al., 2015).

Gasification is another pathway for phosphorous recovery. Typically, raw phosphate or ash is fed into an electric arc-furnace at temperatures over the ash's melting point. Phosphorous is reduced to $\mathrm{P}_{4}$ gas together with carbon dioxide and dust. After flue gas treatment, phosphorous was condensed 
and stored in a water bath with a purity of over $99.9 \%$ (Tervahauta et al., 2014). What is more, phosphorous could be vaporized and recovered as a pure phosphorous element using the InduCarb reactor, with a temperature of between 1300 and $1600{ }^{\circ} \mathrm{C}$ (Schonberg et al., 2014). Phosphorous and $\mathrm{CO}$ leave the reactor in the gas phase and are further treated: $\mathrm{CO}$ could be used for energy production and phosphorous was recovered in the form of iron $-\mathrm{P}$ alloy. Based on the above, the advantages and disadvantages of each technology together with the identification of potential compounds that might hinder its application were detailed in Table 3.

\subsubsection{TRL assessment}

From the literature review, the occurrence of each technology in literature was divided into lab, pilot and full scale, and the result is shown in Figure 2. TRL ranges and scores were then calculated and are summarized in Table 4.

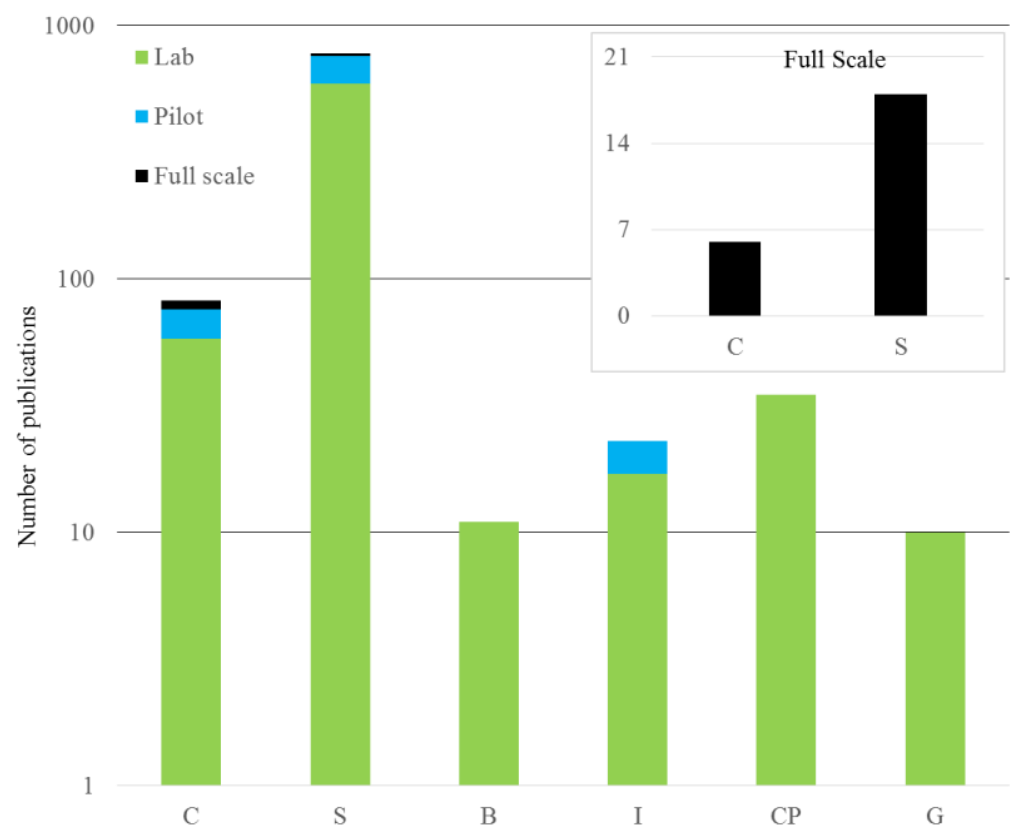

Figure 2: Number of lab, pilot and full-scale applications of key phosphorous recovery technologies (symbols are defined in Table 3)

Despite a large number of technologies that were available at lab and pilot scale levels, these technologies required a significant financial undertaking to commercialise (James, 2017). As defined by James (2017), the percentage of research and development cost for each TRL score was the amount spent thus far on development to the percentage of the total estimated cost to complete a 
project development loop. For example, a TRL 1 spent 1 - 4\% of total cost, TRL 4 spent $12-26 \%$ of total cost, while TRL 9 spent $100 \%$.

Table 4: TRLs for different phosphorous recovery technologies

\begin{tabular}{|c|c|c|c|}
\hline & $\begin{array}{l}\text { TRL } \\
\text { range }\end{array}$ & $\begin{array}{l}\text { TRL } \\
\text { score }\end{array}$ & Remarks \\
\hline Composting & 7 to 9 & 9 & $\begin{array}{l}\text { Excellent technological 'knowhow' and } \\
\text { large number of applications }\end{array}$ \\
\hline $\begin{array}{l}\text { Struvite } \\
\text { Crystallization }\end{array}$ & 7 to 9 & 9 & $\begin{array}{l}\text { Some technical 'knowhow', but with a } \\
\text { large number of full scale applications }\end{array}$ \\
\hline Biomineralization & 1 to 3 & 1 & A few studies on reaction mechanisms \\
\hline Incineration & 4 to 6 & 6 & $\begin{array}{l}\text { A few pilot scale plants in operation, good } \\
\text { technical 'knowhow' }\end{array}$ \\
\hline Calcium P & 1 to 3 & 3 & Concept proven with pilot operations \\
\hline Gasification & 4 to 6 & 5 & $\begin{array}{l}\text { A proven concept and good technical } \\
\text { knowhow }\end{array}$ \\
\hline
\end{tabular}

As can be seen in Table 4, composting and struvite crystallization were the only two technologies that have currently being validated and implemented in industry, indicating that there are much less research and development costs for future application. In comparison, calcium phosphate, gasification and incineration are well understood and are able to be implemented given sufficient technology development. However, reaction mechanisms and potential influential factors for biomineralization are not well understood yet. Therefore, lack of mature technologies, as well as the cost of transitioning them into feasible solutions are barriers for wide spread commercialisation. From a government policy point of view, such TRL transition can be aided by grants for academic and industrial collaborative projects that specifically transform phosphorous recovery technology currently in pilot scale for commercialization.

\subsection{Step 4: Economic analysis}

As discussed in Section 3.3, struvite crystallization is a mature technology for phosphorous recovery from aqueous solution, and composting is currently available for phosphorous recovery from solid waste. As this paper used a wastewater treatment plant as a case study, from this point onwards, only struvite crystallization will be discussed. With details listed in Table 5, a positive discounted value of future cash flow of $\$ 1.7$ million USD is calculated for the base case. As long as the capital cost of a struvite crystallization unit is less than 1.7 million, the process is profitable. However, wastewater composition, plant operation conditions and market environment vary over time. It is thus important to understand key variables affect the PV calculation using sensitivity analysis. This allows a robust understanding of the overall profitability of phosphorous recovery under market, economic and operating conditions that can be expected in reality. 
Table 5: Process variables considered in case study

\begin{tabular}{|c|c|c|c|c|c|c|}
\hline & \multicolumn{2}{|c|}{ Case Study } & \multicolumn{3}{|c|}{ Sensitivity Analysis } & \multirow{2}{*}{ Remarks } \\
\hline & Value & Unit & Symbol & -1 & 1 & \\
\hline P Concentration & 5 & $\mathrm{mg} / \mathrm{L}$ & A & 4 & 10 & Inorganic $\mathrm{PO}_{4}{ }^{3-}$ in wastewater \\
\hline $\begin{array}{l}\text { P Enrichment } \\
\text { Efficiency }\end{array}$ & 60 & $\%$ & $\mathrm{~B}$ & 50 & 90 & $\begin{array}{l}\text { An index of total } \mathrm{P} \text { entering the struvite } \\
\text { recovery unit }\end{array}$ \\
\hline $\begin{array}{l}\text { Struvite Recovery } \\
\text { Efficiency }\end{array}$ & 60 & $\%$ & $\mathrm{C}$ & 50 & 100 & $\begin{array}{l}\text { An index of production and collection } \\
\text { efficiency during struvite recovery }\end{array}$ \\
\hline $\mathrm{Mg} / \mathrm{Ca}$ ratio & 1.1 & - & $\mathrm{D}$ & 1.1 & 1.8 & $\begin{array}{l}\text { Additional } \mathrm{Mg} \text { is required when } \mathrm{Ca} \\
\text { concentration increases }\end{array}$ \\
\hline Struvite Price & 740 & $\$$ & $\mathrm{E}$ & 300 & 800 & Price of struvite as fertilizer \\
\hline Magnesium Price & 400 & $\$$ & $\mathrm{~F}$ & 300 & 1000 & $\begin{array}{l}\text { Price of magnesium sources per ton, } \\
\text { varying between } \mathrm{MgCl}_{2}, \mathrm{MgCO}_{3} \text {, } \\
\mathrm{Mg}(\mathrm{OH})_{2}\end{array}$ \\
\hline Alkali Price & 200 & $\$$ & G & 150 & 500 & $\begin{array}{l}\text { Alkali used to improve } \mathrm{pH} \text { for struvite } \\
\text { recovery, varying between } \mathrm{NaOH} \text {, } \\
\mathrm{Mg}(\mathrm{OH})_{2}\end{array}$ \\
\hline Discount Rate & 15 & $\%$ & $\mathrm{H}$ & 0.05 & 0.25 & $\begin{array}{l}\text { The percentage devaluation of future } \\
\text { revenue streams }\end{array}$ \\
\hline Volume & 550000 & $\mathrm{~m}^{3} /$ day & - & - & - & Assume no change over time \\
\hline Influent $\mathrm{pH}$ & 6.5 & - & - & - & - & Not used in DoE as not sensitive \\
\hline P Enrichment Factor & 30 & - & - & - & - & Not used in DoE as not sensitive \\
\hline Maintenance Cost & 100000 & $\$$ & - & - & - & $\begin{array}{l}\text { Fixed as estimated for } 0.25 \text { Full time } \\
\text { Equivalent person plus maintenance }\end{array}$ \\
\hline Payback Period & 10 & & - & - & - & A payback period of ten-years is used \\
\hline Electricity Usage & 0.15 & Kwh & - & - & - & $\begin{array}{l}\text { Per ton of wastewater processed, not used } \\
\text { as it is insignificant }\end{array}$ \\
\hline Electricity Price & 0.2 & $\$$ & - & - & - & Not used as it is insignificant \\
\hline
\end{tabular}

\subsection{Step 5: Sensitivity Analysis}

DoE was conducted in Design Expert software (8.0.7) for sensitivity analysis. The ANOVA analysis (shown in Table 5, where only significant terms are reported) give an F-value of 105.4, meaning that the model employed is significant. There is only a $0.01 \%$ chance that 'model Fvalues' this large would occur due to noise. The $\mathrm{R}^{2}$ is a measure of the goodness of fit of the model used to explain the data. The calculated $\mathrm{R}^{2}$ is 0.93 and adjusted $\mathrm{R}^{2}$ is 0.94 , respectively.

Adequate precision is a signal to noise ratio that compares the range of the predicted values at the design points to the average prediction error. Ratios higher than 4 indicate adequate model discrimination (Ye, 2010). In the developed model, a ratio of 63.0 implies the model could be used to navigate the designed space. 


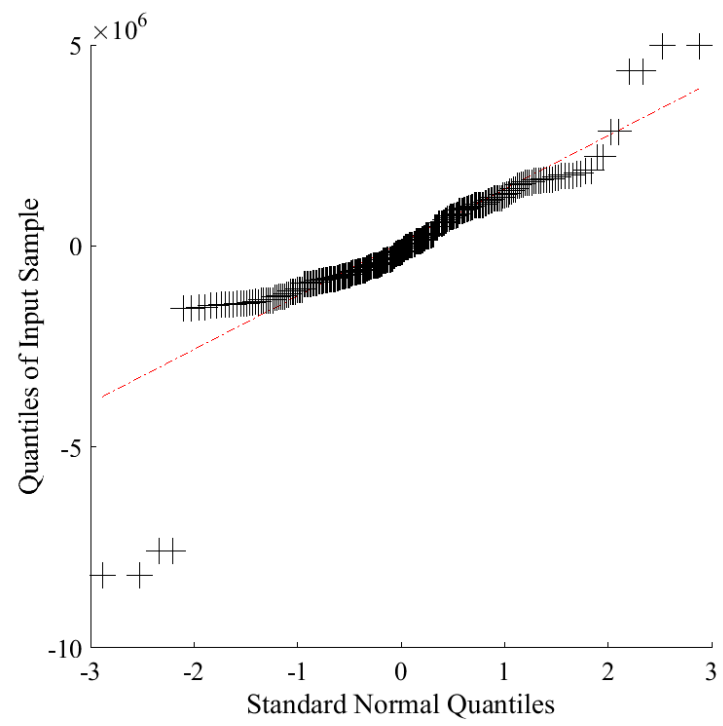

Figure 3: quantile-quantile plot of designed conditions

A quantile-quantile plot of quantiles displays the sample data, $x$, versus the theoretical quantiles from a normal distribution. The plot appears linear if the distribution of $\mathrm{x}$ is normal. A quantilequantile (Q-Q) plot is shown in Figure 3, where the data lies approximately in a straight line, indicating that the underlying distribution is normal. Thus, the model is able to represent the experimental data.

The present value (PV) of future cash flows of 256 scenarios (shown in the appendix) for sensitivity analysis is plotted in Figure 4. As can be seen, a positive NPV was obtained after run 187, where most scenarios (72\%) gave a negative NPV for the different process conditions. However, most negative PV scenarios are close to breakeven, which can be profitable or break-even if financial assistance is extended by policymakers. By considering the fact that phosphorous recovery reduces the nutrient load in downstream units, and reduces pipeline fouling in large wastewater treatment facilities (Huang et al., 2019), phosphorous recovery is still recommended. 


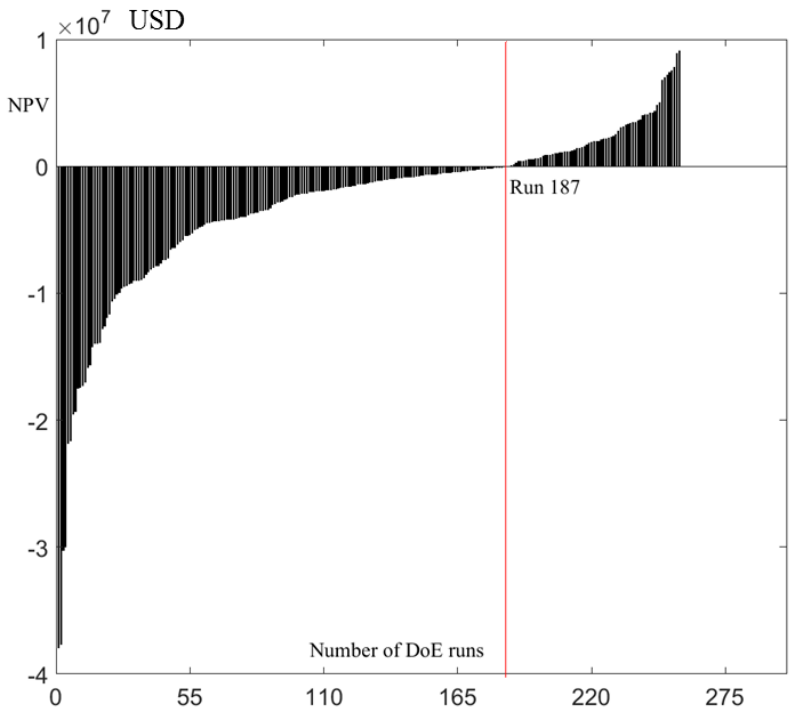

Figure 4: NPV of the Future Cash Flows

Details on how the above-mentioned factors (listed in Table 5) contribute to variations in PV was shown in Table 6. As can be seen, market variables such as magnesium and struvite price account for $42.5 \%$ and $13.5 \%$ of the total variation in PV. That is to say, more than $60 \%$ variation in PV is from market variation, which is out of an engineer's/scientist's control. Struvite recovery efficiency, $\mathrm{PO}_{4}{ }^{3-}$ enrichment efficiency and magnesium dosage ratio have an impact of $16.3 \%, 12.0 \%$ and $8.5 \%$ respectively.

Table 6: Contribution of variables to PV change

\begin{tabular}{clc}
\hline Variable type & Variables & Contribution to PV (\%) \\
\hline & C-Struvite recovery P & 16.3 \\
& efficiency & 12.0 \\
Technical & B-Enrichment efficiency & 8.5 \\
& D-Mg dosage ratio & 3.0 \\
\hline \multirow{5}{*}{ Market } & A-P Concentration & 42.5 \\
& F-Magnesium price & 13.5 \\
& E-Struvite price & 4.2 \\
& H-Discount Rate & 0.2 \\
\hline
\end{tabular}

As a result of this analysis. It may be concluded that, future technology development on improving the struvite recovery efficiency may be more valuable than enriching phosphorus concentration in the influent. This is contradictory to previous research (Li et al., 2016), most of which reported that influent $\mathrm{PO}_{4}{ }^{3-}$ concentration affects the process performance significantly. This might be because of 
the ignorance of market and process efficiency. From the current study, the total amount of phosphorous rather than the concentration in the influent is more important during the implementation of a phosphorous recovery technology.

As phosphorous recovery via struvite crystallization produces a $\mathrm{CO}_{2}$ abatement of about $100 \mathrm{~kg} / \mathrm{T}$ less than traditional phosphate rock extraction (Yetilmezsoy et al., 2017), with a cost of $\mathrm{CO}_{2}$ emissions is between 20 - 120 USD a tonne, an additional environmental profit of 2-12 USD could be generated per each tonne of struvite recovered. This gives a 4,000-24,000 USD in total for the wastewater treatment plant investigated, without considering extra packaging and transportation cost in traditional phosphate rock extraction processes. Although this is a minor amount, it can shift some scenarios to positive PV projects, which means they can be operated without making economic losses.

It is also important to note that this analysis has not considered the investment necessary for building a phosphorous recovery plant, which would make a large number of scenarios explored unprofitable in a strict economic sense. This can be somewhat blanketed by preferential borrowing conditions for investors in phosphorous recovery endorsed by the governments or tax credits offered for Waste water treatment plant operators for investing in P recovery units.

\subsection{Implications}

Formateret: Skrifttype: Fed

Morocco, China, Algeria and the USA account for almost $85 \%$ of the world's phosphate rock reserves ( $\mathrm{Li}$ et al., 2018), therefore, large phosphorous consumers, such as Japan and EU, may adopt preferential policies to make phosphorous recovery economically viable by increased phosphate import tariffs or provide phosphorous recovery subsidies. At the same time, specific funding transferring current pilot or lab scale phosphorous recovery technologies to full scale processes should be introduced. This in turn will provide a better technology choice for future phosphorous recovery projects. What is more, a combination of phosphorous recovery with other pre-treatment or post-treatment technologies is recommended, which helps to increase the process efficiency (for example, increase the struvite recovery efficiency or $\mathrm{PO}_{4}{ }^{3-}$ enrichment efficiency), add extra value and reduce the capital and operational costs. Due to the lack of data, only struvite precipitation was used to demonstrate the usage of the proposed framework. Current barriers based on this process for efficient phosphorous recovery are: Based on the above discussion, current barriers for the commercialization of phosphors recovery are:

1) Only struvite crystallization and composting are ready for commercialization, while other technologies require significant investment in research and development;

Slettet: $\mathbb{I}$

\section{Slettet: $\mathbb{I}$}


2) Government awareness of the phosphorus resource crisis and role of phosphorous in water quality is insufficient;

3) The recovery process is sensitive to influent composition, making it difficult to control and making the process unprofitable in a strict economic sense;

4) Market price variation significantly affects the process economics, while the current low value added product did not increase the process income significantly.

\section{Conclusions}

An enhanced methodology was proposed to identify barriers to the commercialisation of current phosphorous recovery technologies. The economic payback of $\mathrm{P}$ recovery in the current state of affairs is weak, while only struvite crystallization and composting are currently at high technology maturity that makes an industrial implementation possible. Sensitivity analysis illustrated that the phosphorus concentration in a given stream is only one of the many factors that dictate the profitability of a given implementation. Struvite crystallization, as currently the only mature process for phosphorous recovery from aqueous streams, is marginally non-profitable, where both the market (sales and purchasing cost) and operating conditions have a significant impact on its PV. Government subsidies to $\mathrm{P}$ recovery units or imposing taxes on extracted phosphorous is recommended to overcome the current gap. In terms of struvite crystallization, further research on process efficiency improvement (e.g. struvite recovery efficiency, $\mathrm{PO}_{4}{ }^{3-}$ enrichment efficiency and magnesium dosage ratio) is required to increase its overall profitability. The proposed methodology could also be extended to identify barriers in other resource recovery technologies. 


\section{References}

Arnout, S., Nagels, E., 2016. Modelling thermal phosphorus recovery from sewage sludge ash, Calphad, 55, $26-31$.

Atilgan, B., Azapagic, A., 2016. Assessing the Environmental Sustainability of Electricity Generation in Turkey on a Life Cycle Basis, Energies, 9, 1, 31.

Azapagic, A., Stamford, L., Youds, L., Barteczko-Hibbert, C., 2016. Towards sustainable production and consumption: A novel DEcision-Support Framework IntegRating Economic, Environmental and Social Sustainability (DESIRES), Computers \& Chemical Engineering, 91, 93 103.

Cieślik, B., Konieczka, P., 2017. A review of phosphorus recovery methods at various steps of wastewater treatment and sewage sludge management. The concept of "no solid waste generation" and analytical methods, Journal of Cleaner Production, 142, 1728-1740.

De Lun, M.D., Abarca, R.R., Su, C. C., Huanh, Y. H., Lu, M.C., 2015. Multivariate optimization of phosphate removal and recovery from aqueous solution by struvite crystallization in a fluidized-bed reactor, $496-505$.

Egle, L., Rechberger, H., Zessner, M., 2015. Overview and description of technologies for recovering phosphorus from municipal wastewater, Resources, Conservation and Recycling, 105, $325-346$

Elser, J., Bennett, E., 2011. Phosphorus cycle: A broken biogeochemical cycle, Nature 478, 29-31.

Huang, H., Zhang, D., Guo, G., Jiang, Y., Wang, M., Zhang, P., Li, J., 2018. Dolomite application for the removal of nutrients from synthetic swine wastewater by a novel combined electrochemical process, Chemical Engineering Journal, 335, 1, 665 - 675.

James, L., 2017. Technology Readiness Level (TRL) vs. Percent Development Cost, 2017 ICEAA Professional Development \& Training Workshop, Oregon. Portland.

Kataki, S., West, H., Clarke, M., Baruah, D.C., 2016. Phosphorus recovery as struvite: Recent concerns for use of seed, alternative $\mathrm{Mg}$ source, nitrogen conservation and fertilizer potential, Resources, Conservation and Recycling, 107, 142 - 156.

Kumar, R., Pal, P., 2015. Assessing the feasibility of $\mathrm{N}$ and $\mathrm{P}$ recovery by struvite precipitation from nutrient-rich wastewater: a review, Environmental Science and Pollution Research, 22, 22, 17453-17464. 
Li, B., Boiarkina, I., Young, B., Yu, W., 2015, Substance flow analysis of phosphorus within New Zealand and comparison with other countries, Science of the Total Environment, 527, 483-492.

Li, B., Boiarkina, I., Young, B., Yu, W., 2016. Quantification and mitigation of the negative impact of calcium on struvite purity, Advanced Powder Technology, 27, 6, 2354-2362.

Li, B., Boiarkina, Li, B., Boiarkina, I., Young, B., Yu, W., Singhal, N., 2018. Prediction of Future Phosphate Rock: A Demand Based Model, Journal of Environmental Informatics, 1, 41 - 53.

Li, H., Yao, Q., Yu, S., Huang, Y.R., Chen, X, D., Fu, S.Q., Zhou, G.T., 2017. Bacterially mediated morphogenesis of struvite and its implication for phosphorus recovery, American Mineralogist, 102, 2, 381-390.

Loganathan, P., Vigneswaran, S., Kandasamy, J., Bolan, N., 2014. Removal and Recovery of Phosphate From Water Using Sorption, Critical Reviews in Environmental Science and Technology, 847-907.

Luthra, S., Govindan, K., Kannan, D., Mangla, S.K., Garg, C.P., 2017. An integrated framework for sustainable supplier selection and evaluation in supply chains, Journal of Cleaner Production, 140, 3, 1686-1698.

Mansouri, S.S., Udugama, L.A., Cignitti, S., Mitic, A., Flores-Alsina, X., Gernaey, K.V., 2017. Resource recovery from bio-based production processes: a future necessity? Current Opinion in Chemical Engineering, 18, $1-9$.

Melia, P.M., Cundy, A.B., Sohi, S.P., Hooda, P.S., Busquets, R., 2017. Trends in the recovery of phosphorus in bioavailable forms from wastewater, Chemosphere, 186, 381-395.

Munir, T., Li, B., Boiarkina, I. A., Baroutian, S., Yu, W., Young, B. R., 2017. Phosphate recovery from hydrothermally treated sewage sludge using struvite precipitation. Bioresource Technology, 239, 171-179.

Nakakubo, T., Tokai, A., Ohno, K., 2012. Comparative assessment of technological systems for recycling sludge and food waste aimed at greenhouse gas emissions reduction and phosphorus recovery, Journal of Cleaner Production, 168, 803-813.

Parasuraman, A., 2000. Technology Readiness Index (Tri): A Multiple-Item Scale to Measure Readiness to Embrace New Technologies, Journal of Service Research, 2, 4, 307-320.

Rahaman, M.S., Mavinic, D.S., Meikleham, A., Ellis, N., 2014. Modeling phosphorus removal and recovery from anaerobic digester supernatant through struvite crystallization in a fluidized bed reactor, Water Research, 51, 1- 10. 
Ribarova. I., Dimitrova, S., Lambeva, R., Wintgens., T., Stemann, J., Remmen, K., 2017. Phosphorus recovery potential in Sofia WWTP in view of the national sludge management strategy, Resources, Conservation and Recycling, 116, 152-159.

Rybicka J., Tiwari, A., Leeke, G.A., 2016. Technology readiness level assessment of composites recycling technologies, Journal of Cleaner Production, 112, 1, 1001 -10212.

Samir, K.C., Wolfgang, L., 2017. The human core of the shared socioeconomic pathways: Population scenarios by age, sex and level of education for all countries to 2100, Global Environmental Change, 42,181 - 192.

Schoumans, O.F., Bouraoui, F., Kabbe, C., Oenema, O., van Dijk, K., C., 2015. Phosphorus management in Europe in a changing world, AMBIO, 44, 180 - 192.

Soares, A., Veesam, M., Simoes, F., Wood, E., Parsons, S.A., Stephenson, T., 2013. Bio-Struvite: A New Route to Recover Phosphorus from Wastewater, CLEAN-Soil, Air, Water, 42, 7, 994-997.

Tervahauta, T., Van der Weijden, R.,D., Flemming, R.L., Leal, L.H., Zeeman, G., Buisman, C., 2014. Calcium phosphate granulation in anaerobic treatment of black water: A new approach to phosphorus recovery, Water Research, 48, 632-642.

Tura, N., Hanski, J., Ahola, T., Stahle, M., Piiparinen, S., Valkokari, P., 2019. Unlocking circular business: A framework of barriers and drivers, 212, 90-98.

Udugama, I.A., Mansouri, S.S., Mitic, A., Flores-Alsina, X., Gernaey, K.V., 2017. Perspectives on Resource Recovery from Bio-Based Production Processes: From Concept to Implementation, Processes 2017, 5, 3, 48 .

\section{Xia, D., Zhang, M., Yu, Q., Yu, T., 2019. Developing a framework to identify barriers of Green} technology adoption for enterprises, Resources, Conservation and Recycling, 143, 99-110.

Yetilmezsoy, K., Ilhan, F., Kocak, E., Akbin, H.M., 2017. Feasibility of struvite recovery process for fertilizer industry: A study of financial and economic analysis, Journal of Cleaner Production, $2017,152,88-102$.

Zamora, P., Georgieva, T., Salcedo, I., Elzinga, N., Kuntke, P., Buisman, C., 2016. Long - term operation of a pilot - scale reactor for phosphorus recovery as struvite from source - separated urine, Journal of Chemical Technology \& Biotechnology, 92, 5, 1035 - 1045. 
Appendix: PV result for sensitivity analysis

\begin{tabular}{|c|c|c|c|c|c|c|c|c|c|}
\hline $\begin{array}{c}\text { Run } \\
\text { numbe } \\
\mathbf{r}\end{array}$ & $\begin{array}{c}\mathbf{P} \\
\begin{array}{c}\text { Concentration } \\
(\mathbf{m g} / \mathbf{L})\end{array}\end{array}$ & $\begin{array}{c}\mathbf{P} \\
\text { Enrichment } \\
\text { Efficiency } \\
(\%)\end{array}$ & $\begin{array}{c}\text { Struvite } \\
\text { Recovery } \\
\text { Efficiency } \\
(\%)\end{array}$ & $\underset{\text { ratio }}{\mathrm{Mg} / \mathrm{Ca}}$ & $\begin{array}{c}\text { Struvite } \\
\text { (USD) }\end{array}$ & $\begin{array}{l}\text { Magnesiu } \\
\text { m (USD) }\end{array}$ & $\begin{array}{l}\text { Alkali } \\
\text { (USD) }\end{array}$ & $\begin{array}{l}\text { Discount } \\
\text { Rate (\%) }\end{array}$ & NPV (USD) \\
\hline 1 & 10 & 90 & 100 & 1.8 & 300 & 1000 & 500 & 0.05 & $\$ 37,929,162.0$ \\
\hline 2 & 10 & 90 & 100 & 1.8 & 300 & 1000 & 150 & 0.05 & $\$ 37,691,332.5$ \\
\hline 3 & 10 & 90 & 100 & 1.8 & 800 & 1000 & 500 & 0.05 & $\$ 30,284,644.4$ \\
\hline 4 & 10 & 90 & 100 & 1.8 & 800 & 1000 & 150 & 0.05 & $\$ 30,046,815.0$ \\
\hline 5 & 10 & 90 & 100 & 1.1 & 300 & 1000 & 500 & 0.05 & $\$ 21,875,675.1$ \\
\hline 6 & 10 & 90 & 100 & 1.1 & 300 & 1000 & 150 & 0.05 & $\$ 21,637,845.6$ \\
\hline 7 & 10 & 50 & 100 & 1.8 & 300 & 1000 & 500 & 0.05 & $\$ 19,582,319.8$ \\
\hline 8 & 10 & 50 & 100 & 1.8 & 300 & 1000 & 150 & 0.05 & $\$ 19,344,490.3$ \\
\hline 9 & 10 & 90 & 100 & 1.8 & 300 & 1000 & 500 & 0.25 & $\$ 17,538,312.1$ \\
\hline 10 & 10 & 90 & 100 & 1.8 & 300 & 1000 & 150 & 0.25 & $\$ 17,428,340.6$ \\
\hline 11 & 10 & 90 & 50 & 1.8 & 300 & 1000 & 500 & 0.05 & $\$ 17,288,964.5$ \\
\hline 12 & 10 & 90 & 50 & 1.8 & 300 & 1000 & 150 & 0.05 & $\$ 17,051,135.1$ \\
\hline 13 & 4 & 90 & 100 & 1.8 & 300 & 1000 & 500 & 0.05 & $\$ 15,912,951.3$ \\
\hline 14 & 4 & 90 & 100 & 1.8 & 300 & 1000 & 150 & 0.05 & $\$ 15,675,121.9$ \\
\hline 15 & 10 & 90 & 100 & 1.1 & 800 & 1000 & 500 & 0.05 & $\$ 14,231,157.5$ \\
\hline 16 & 10 & 90 & 100 & 1.8 & 800 & 1000 & 500 & 0.25 & $\$ 14,003,513.8$ \\
\hline 17 & 10 & 90 & 100 & 1.1 & 800 & 1000 & 150 & 0.05 & $\$ 13,993,328.0$ \\
\hline 18 & 10 & 90 & 100 & 1.8 & 800 & 1000 & 150 & 0.25 & $\$ 13,893,542.3$ \\
\hline 19 & 4 & 90 & 100 & 1.8 & 800 & 1000 & 500 & 0.05 & $\$ 12,855,144.3$ \\
\hline 20 & 4 & 90 & 100 & 1.8 & 800 & 1000 & 150 & 0.05 & $\$ 12,617,314.9$ \\
\hline 21 & 10 & 50 & 100 & 1.8 & 800 & 1000 & 500 & 0.05 & $\$ 11,937,802.2$ \\
\hline 22 & 10 & 50 & 100 & 1.8 & 800 & 1000 & 150 & 0.05 & $\$ 11,699,972.8$ \\
\hline 23 & 10 & 50 & 100 & 1.1 & 300 & 1000 & 500 & 0.05 & $\$ 10,663,715.9$ \\
\hline 24 & 10 & 50 & 100 & 1.1 & 300 & 1000 & 150 & 0.05 & $\$ 10,425,886.5$ \\
\hline 25 & 10 & 90 & 100 & 1.1 & 300 & 1000 & 500 & 0.25 & $\$ 10,115,235.8$ \\
\hline 26 & 10 & 90 & 100 & 1.1 & 300 & 1000 & 150 & 0.25 & $\$ 10,005,264.3$ \\
\hline 27 & 10 & 90 & 50 & 1.8 & 800 & 1000 & 500 & 0.05 & $-\$ 9,644,446.9$ \\
\hline
\end{tabular}




\begin{tabular}{|c|c|c|c|c|c|c|c|c|c|}
\hline 28 & 4 & 90 & 100 & 1.1 & 300 & 1000 & 500 & 0.05 & $-\$ 9,491,556.6$ \\
\hline 29 & 10 & 90 & 50 & 1.8 & 800 & 1000 & 150 & 0.05 & $-\$ 9,406,617.5$ \\
\hline 30 & 10 & 90 & 50 & 1.1 & 300 & 1000 & 500 & 0.05 & $-\$ 9,262,221.0$ \\
\hline 31 & 4 & 90 & 100 & 1.1 & 300 & 1000 & 150 & 0.05 & $-\$ 9,253,727.1$ \\
\hline 32 & 10 & 50 & 100 & 1.8 & 300 & 1000 & 500 & 0.25 & $-\$ 9,054,796.3$ \\
\hline 33 & 10 & 90 & 100 & 1.8 & 300 & 300 & 500 & 0.05 & $-\$ 9,032,885.5$ \\
\hline 34 & 10 & 90 & 50 & 1.1 & 300 & 1000 & 150 & 0.05 & $-\$ 9,024,391.6$ \\
\hline 35 & 10 & 50 & 100 & 1.8 & 300 & 1000 & 150 & 0.25 & $-\$ 8,944,824.8$ \\
\hline 36 & 10 & 90 & 100 & 1.8 & 300 & 300 & 150 & 0.05 & $-\$ 8,795,056.1$ \\
\hline 37 & 4 & 50 & 100 & 1.8 & 300 & 1000 & 500 & 0.05 & $-\$ 8,574,214.5$ \\
\hline 38 & 4 & 50 & 100 & 1.8 & 300 & 1000 & 150 & 0.05 & $-\$ 8,336,385.0$ \\
\hline 39 & 10 & 50 & 50 & 1.8 & 300 & 1000 & 500 & 0.05 & $-\$ 8,115,543.4$ \\
\hline 40 & 10 & 90 & 50 & 1.8 & 300 & 1000 & 500 & 0.25 & $-\$ 7,994,356.8$ \\
\hline 41 & 10 & 90 & 50 & 1.8 & 300 & 1000 & 150 & 0.25 & $-\$ 7,884,385.3$ \\
\hline 42 & 10 & 50 & 50 & 1.8 & 300 & 1000 & 150 & 0.05 & $-\$ 7,877,714.0$ \\
\hline 43 & 4 & 90 & 50 & 1.8 & 300 & 1000 & 500 & 0.05 & $-\$ 7,656,872.4$ \\
\hline 44 & 4 & 90 & 50 & 1.8 & 300 & 1000 & 150 & 0.05 & $-\$ 7,419,042.9$ \\
\hline 45 & 4 & 90 & 100 & 1.8 & 300 & 1000 & 500 & 0.25 & $-\$ 7,358,093.1$ \\
\hline 46 & 4 & 90 & 100 & 1.8 & 300 & 1000 & 150 & 0.25 & $-\$ 7,248,121.6$ \\
\hline 47 & 10 & 90 & 100 & 1.1 & 800 & 1000 & 500 & 0.25 & $-\$ 6,580,437.5$ \\
\hline 48 & 10 & 90 & 100 & 1.1 & 800 & 1000 & 150 & 0.25 & $-\$ 6,470,466.0$ \\
\hline 49 & 4 & 90 & 100 & 1.1 & 800 & 1000 & 500 & 0.05 & $-\$ 6,433,749.5$ \\
\hline 50 & 4 & 90 & 100 & 1.1 & 800 & 1000 & 150 & 0.05 & $-\$ 6,195,920.1$ \\
\hline 51 & 4 & 90 & 100 & 1.8 & 800 & 1000 & 500 & 0.25 & $-\$ 5,944,173.8$ \\
\hline 52 & 4 & 90 & 100 & 1.8 & 800 & 1000 & 150 & 0.25 & $-\$ 5,834,202.3$ \\
\hline 53 & 10 & 50 & 100 & 1.8 & 800 & 1000 & 500 & 0.25 & $-\$ 5,519,998.1$ \\
\hline 54 & 4 & 50 & 100 & 1.8 & 800 & 1000 & 500 & 0.05 & $-\$ 5,516,407.4$ \\
\hline 55 & 10 & 50 & 100 & 1.8 & 800 & 1000 & 150 & 0.25 & $-\$ 5,410,026.6$ \\
\hline 56 & 4 & 50 & 100 & 1.8 & 800 & 1000 & 150 & 0.05 & $-\$ 5,278,578.0$ \\
\hline 57 & 4 & 50 & 100 & 1.1 & 300 & 1000 & 500 & 0.05 & $-\$ 5,006,772.9$ \\
\hline 58 & 10 & 50 & 100 & 1.1 & 300 & 1000 & 500 & 0.25 & $-\$ 4,930,865.0$ \\
\hline 59 & 10 & 50 & 100 & 1.1 & 300 & 1000 & 150 & 0.25 & $-\$ 4,820,893.5$ \\
\hline 60 & 4 & 50 & 100 & 1.1 & 300 & 1000 & 150 & 0.05 & $-\$ 4,768,943.5$ \\
\hline 61 & 4 & 90 & 50 & 1.8 & 800 & 1000 & 500 & 0.05 & $-\$ 4,599,065.3$ \\
\hline 62 & 10 & 90 & 50 & 1.8 & 800 & 1000 & 500 & 0.25 & $-\$ 4,459,558.6$ \\
\hline 63 & 4 & 90 & 50 & 1.1 & 300 & 1000 & 500 & 0.05 & $-\$ 4,446,175.0$ \\
\hline 64 & 4 & 90 & 100 & 1.1 & 300 & 1000 & 500 & 0.25 & $-\$ 4,388,862.6$ \\
\hline 65 & 4 & 90 & 50 & 1.8 & 800 & 1000 & 150 & 0.05 & $-\$ 4,361,235.9$ \\
\hline 66 & 4 & 90 & 100 & 1.8 & 300 & 300 & 500 & 0.05 & $-\$ 4,354,440.8$ \\
\hline 67 & 10 & 90 & 50 & 1.8 & 800 & 1000 & 150 & 0.25 & $-\$ 4,349,587.1$ \\
\hline 68 & 10 & 90 & 50 & 1.1 & 300 & 1000 & 500 & 0.25 & $-\$ 4,282,818.7$ \\
\hline 69 & 4 & 90 & 100 & 1.1 & 300 & 1000 & 150 & 0.25 & $-\$ 4,278,891.1$ \\
\hline 70 & 10 & 90 & 100 & 1.1 & 300 & 300 & 500 & 0.05 & $-\$ 4,216,839.4$ \\
\hline 71 & 4 & 90 & 50 & 1.1 & 300 & 1000 & 150 & 0.05 & $-\$ 4,208,345.5$ \\
\hline 72 & 10 & 90 & 100 & 1.8 & 300 & 300 & 500 & 0.25 & $-\$ 4,176,774.7$ \\
\hline 73 & 10 & 90 & 50 & 1.1 & 300 & 1000 & 150 & 0.25 & $-\$ 4,172,847.2$ \\
\hline 74 & 4 & 90 & 100 & 1.8 & 300 & 300 & 150 & 0.05 & $-\$ 4,116,611.3$ \\
\hline 75 & 10 & 90 & 100 & 1.8 & 300 & 300 & 150 & 0.25 & $-\$ 4,066,803.2$ \\
\hline
\end{tabular}




\begin{tabular}{|c|c|c|c|c|c|c|c|c|c|}
\hline 76 & 4 & 50 & 50 & 1.8 & 300 & 1000 & 500 & 0.05 & $-\$ 3,987,503.9$ \\
\hline 77 & 10 & 90 & 100 & 1.1 & 300 & 300 & 150 & 0.05 & $-\$ 3,979,010.0$ \\
\hline 78 & 4 & 50 & 100 & 1.8 & 300 & 1000 & 500 & 0.25 & $-\$ 3,964,686.8$ \\
\hline 79 & 4 & 50 & 100 & 1.8 & 300 & 1000 & 150 & 0.25 & $-\$ 3,854,715.3$ \\
\hline 80 & 10 & 50 & 50 & 1.8 & 300 & 1000 & 500 & 0.25 & $-\$ 3,752,598.9$ \\
\hline 81 & 4 & 50 & 50 & 1.8 & 300 & 1000 & 150 & 0.05 & $-\$ 3,749,674.5$ \\
\hline 82 & 10 & 50 & 50 & 1.1 & 300 & 1000 & 500 & 0.05 & $-\$ 3,656,241.5$ \\
\hline 83 & 10 & 50 & 50 & 1.8 & 300 & 1000 & 150 & 0.25 & $-\$ 3,642,627.4$ \\
\hline 84 & 4 & 90 & 50 & 1.8 & 300 & 1000 & 500 & 0.25 & $-\$ 3,540,511.0$ \\
\hline 85 & 10 & 50 & 100 & 1.8 & 300 & 300 & 500 & 0.05 & $-\$ 3,528,832.9$ \\
\hline 86 & 4 & 90 & 50 & 1.8 & 300 & 1000 & 150 & 0.25 & $-\$ 3,430,539.5$ \\
\hline 87 & 10 & 50 & 50 & 1.1 & 300 & 1000 & 150 & 0.05 & $-\$ 3,418,412.1$ \\
\hline 88 & 10 & 50 & 100 & 1.8 & 300 & 300 & 150 & 0.05 & $-\$ 3,291,003.4$ \\
\hline 89 & 10 & 50 & 100 & 1.1 & 800 & 1000 & 500 & 0.05 & $-\$ 3,019,198.4$ \\
\hline 90 & 4 & 90 & 100 & 1.1 & 800 & 1000 & 500 & 0.25 & $-\$ 2,974,943.3$ \\
\hline 91 & 4 & 90 & 100 & 1.1 & 800 & 1000 & 150 & 0.25 & $-\$ 2,864,971.8$ \\
\hline 92 & 10 & 90 & 50 & 1.8 & 300 & 300 & 500 & 0.05 & $-\$ 2,840,826.3$ \\
\hline 93 & 10 & 50 & 100 & 1.1 & 800 & 1000 & 150 & 0.05 & $-\$ 2,781,368.9$ \\
\hline 94 & 10 & 90 & 50 & 1.8 & 300 & 300 & 150 & 0.05 & $-\$ 2,602,996.8$ \\
\hline 95 & 4 & 50 & 100 & 1.8 & 800 & 1000 & 500 & 0.25 & $-\$ 2,550,767.5$ \\
\hline 96 & 4 & 50 & 100 & 1.8 & 800 & 1000 & 150 & 0.25 & $-\$ 2,440,796.0$ \\
\hline 97 & 4 & 90 & 100 & 1.1 & 300 & 300 & 500 & 0.05 & $-\$ 2,428,022.3$ \\
\hline 98 & 4 & 50 & 100 & 1.1 & 300 & 1000 & 500 & 0.25 & $-\$ 2,315,114.3$ \\
\hline 99 & 4 & 50 & 100 & 1.1 & 300 & 1000 & 150 & 0.25 & $-\$ 2,205,142.8$ \\
\hline 100 & 4 & 50 & 50 & 1.1 & 300 & 1000 & 500 & 0.05 & $-\$ 2,203,783.1$ \\
\hline 101 & 4 & 90 & 100 & 1.1 & 300 & 300 & 150 & 0.05 & $-\$ 2,190,192.9$ \\
\hline 102 & 4 & 50 & 100 & 1.8 & 300 & 300 & 500 & 0.05 & $-\$ 2,152,819.7$ \\
\hline 103 & 4 & 90 & 50 & 1.8 & 800 & 1000 & 500 & 0.25 & $-\$ 2,126,591.7$ \\
\hline 104 & 4 & 90 & 50 & 1.1 & 300 & 1000 & 500 & 0.25 & $-\$ 2,055,895.8$ \\
\hline 105 & 4 & 90 & 50 & 1.8 & 800 & 1000 & 150 & 0.25 & $-\$ 2,016,620.2$ \\
\hline 106 & 4 & 90 & 100 & 1.8 & 300 & 300 & 500 & 0.25 & $-\$ 2,013,478.2$ \\
\hline 107 & 4 & 50 & 50 & 1.1 & 300 & 1000 & 150 & 0.05 & $-\$ 1,965,953.7$ \\
\hline 108 & 10 & 90 & 100 & 1.1 & 300 & 300 & 500 & 0.25 & $-\$ 1,949,851.8$ \\
\hline 109 & 4 & 50 & 100 & 1.1 & 800 & 1000 & 500 & 0.05 & $-\$ 1,948,965.9$ \\
\hline 110 & 4 & 90 & 50 & 1.1 & 300 & 1000 & 150 & 0.25 & $-\$ 1,945,924.3$ \\
\hline 111 & 4 & 50 & 100 & 1.8 & 300 & 300 & 150 & 0.05 & $-\$ 1,914,990.3$ \\
\hline 112 & 4 & 90 & 100 & 1.8 & 300 & 300 & 150 & 0.25 & $-\$ 1,903,506.7$ \\
\hline 113 & 4 & 90 & 50 & 1.8 & 300 & 300 & 500 & 0.05 & $-\$ 1,877,617.1$ \\
\hline 114 & 4 & 50 & 50 & 1.8 & 300 & 1000 & 500 & 0.25 & $-\$ 1,843,807.9$ \\
\hline 115 & 10 & 90 & 100 & 1.1 & 300 & 300 & 150 & 0.25 & $-\$ 1,839,880.3$ \\
\hline 116 & 4 & 50 & 50 & 1.8 & 300 & 1000 & 150 & 0.25 & $-\$ 1,733,836.4$ \\
\hline 117 & 4 & 50 & 100 & 1.1 & 800 & 1000 & 150 & 0.05 & $-\$ 1,711,136.5$ \\
\hline 118 & 10 & 50 & 50 & 1.1 & 300 & 1000 & 500 & 0.25 & $-\$ 1,690,633.3$ \\
\hline 119 & 4 & 90 & 50 & 1.8 & 300 & 300 & 150 & 0.05 & $-\$ 1,639,787.6$ \\
\hline 120 & 10 & 50 & 100 & 1.8 & 300 & 300 & 500 & 0.25 & $-\$ 1,631,720.0$ \\
\hline 121 & 10 & 90 & 50 & 1.1 & 800 & 1000 & 500 & 0.05 & $-\$ 1,617,703.5$ \\
\hline 122 & 10 & 50 & 50 & 1.1 & 300 & 1000 & 150 & 0.25 & $-\$ 1,580,661.8$ \\
\hline 123 & 10 & 50 & 100 & 1.8 & 300 & 300 & 150 & 0.25 & $-\$ 1,521,748.5$ \\
\hline
\end{tabular}




\begin{tabular}{|c|c|c|c|c|c|c|c|c|c|}
\hline 124 & 10 & 50 & 100 & 1.1 & 800 & 1000 & 500 & 0.25 & $-\$ 1,396,066.8$ \\
\hline 125 & 4 & 90 & 50 & 1.1 & 800 & 1000 & 500 & 0.05 & $-\$ 1,388,367.9$ \\
\hline 126 & 10 & 90 & 100 & 1.8 & 800 & 300 & 500 & 0.05 & $-\$ 1,388,367.9$ \\
\hline 127 & 10 & 90 & 50 & 1.1 & 800 & 1000 & 150 & 0.05 & $-\$ 1,379,874.0$ \\
\hline 128 & 10 & 90 & 50 & 1.8 & 300 & 300 & 500 & 0.25 & $-\$ 1,313,588.2$ \\
\hline 129 & 4 & 90 & 100 & 1.8 & 800 & 300 & 500 & 0.05 & $-\$ 1,296,633.7$ \\
\hline 130 & 10 & 50 & 100 & 1.1 & 800 & 1000 & 150 & 0.25 & $-\$ 1,286,095.3$ \\
\hline 131 & 10 & 90 & 50 & 1.8 & 300 & 300 & 150 & 0.25 & $-\$ 1,203,616.7$ \\
\hline 132 & 4 & 90 & 50 & 1.1 & 800 & 1000 & 150 & 0.05 & $-\$ 1,150,538.5$ \\
\hline 133 & 10 & 90 & 100 & 1.8 & 800 & 300 & 150 & 0.05 & $-\$ 1,150,538.5$ \\
\hline 134 & 4 & 90 & 100 & 1.1 & 300 & 300 & 500 & 0.25 & $-\$ 1,122,709.0$ \\
\hline 135 & 4 & 50 & 100 & 1.1 & 300 & 300 & 500 & 0.05 & $-\$ 1,082,587.2$ \\
\hline 136 & 4 & 90 & 100 & 1.8 & 800 & 300 & 150 & 0.05 & $-\$ 1,058,804.3$ \\
\hline 137 & 4 & 50 & 50 & 1.1 & 300 & 1000 & 500 & 0.25 & $-\$ 1,019,021.6$ \\
\hline 138 & 4 & 90 & 100 & 1.1 & 300 & 300 & 150 & 0.25 & $-\$ 1,012,737.5$ \\
\hline 139 & 4 & 50 & 100 & 1.8 & 300 & 300 & 500 & 0.25 & $-\$ 995,456.3$ \\
\hline 140 & 4 & 50 & 50 & 1.8 & 800 & 1000 & 500 & 0.05 & $-\$ 929,696.9$ \\
\hline 141 & 4 & 90 & 50 & 1.1 & 300 & 300 & 500 & 0.05 & $-\$ 914,407.9$ \\
\hline 142 & 4 & 50 & 50 & 1.1 & 300 & 1000 & 150 & 0.25 & $-\$ 909,050.1$ \\
\hline 143 & 4 & 50 & 100 & 1.1 & 800 & 1000 & 500 & 0.25 & $-\$ 901,195.0$ \\
\hline 144 & 4 & 50 & 100 & 1.8 & 300 & 300 & 150 & 0.25 & $-\$ 885,484.8$ \\
\hline 145 & 4 & 90 & 50 & 1.8 & 300 & 300 & 500 & 0.25 & $-\$ 868,203.6$ \\
\hline 146 & 10 & 50 & 100 & 1.1 & 300 & 300 & 500 & 0.05 & $-\$ 853,251.7$ \\
\hline 147 & 4 & 50 & 100 & 1.1 & 300 & 300 & 150 & 0.05 & $-\$ 844,757.8$ \\
\hline 148 & 4 & 50 & 100 & 1.1 & 800 & 1000 & 150 & 0.25 & $-\$ 791,223.5$ \\
\hline 149 & 4 & 50 & 50 & 1.8 & 300 & 300 & 500 & 0.05 & $-\$ 776,806.5$ \\
\hline 150 & 4 & 90 & 50 & 1.8 & 300 & 300 & 150 & 0.25 & $-\$ 758,232.1$ \\
\hline 151 & 10 & 90 & 50 & 1.1 & 800 & 1000 & 500 & 0.25 & $-\$ 748,020.4$ \\
\hline 152 & 4 & 50 & 50 & 1.8 & 800 & 1000 & 150 & 0.05 & $-\$ 691,867.4$ \\
\hline 153 & 4 & 90 & 50 & 1.1 & 300 & 300 & 150 & 0.05 & $-\$ 676,578.4$ \\
\hline 154 & 4 & 90 & 50 & 1.1 & 800 & 1000 & 500 & 0.25 & $-\$ 641,976.5$ \\
\hline 155 & 10 & 90 & 100 & 1.8 & 800 & 300 & 500 & 0.25 & $-\$ 641,976.5$ \\
\hline 156 & 10 & 90 & 50 & 1.1 & 800 & 1000 & 150 & 0.25 & $-\$ 638,048.9$ \\
\hline 157 & 10 & 50 & 100 & 1.1 & 300 & 300 & 150 & 0.05 & $-\$ 615,422.3$ \\
\hline 158 & 4 & 90 & 100 & 1.8 & 800 & 300 & 500 & 0.25 & $-\$ 599,558.9$ \\
\hline 159 & 4 & 50 & 50 & 1.8 & 300 & 300 & 150 & 0.05 & $-\$ 538,977.1$ \\
\hline 160 & 4 & 90 & 50 & 1.1 & 800 & 1000 & 150 & 0.25 & $-\$ 532,005.0$ \\
\hline 161 & 10 & 90 & 100 & 1.8 & 800 & 300 & 150 & 0.25 & $-\$ 532,005.0$ \\
\hline 162 & 4 & 50 & 100 & 1.1 & 300 & 300 & 500 & 0.25 & $-\$ 500,584.6$ \\
\hline 163 & 4 & 90 & 100 & 1.8 & 800 & 300 & 150 & 0.25 & $-\$ 489,587.4$ \\
\hline 164 & 10 & 50 & 50 & 1.8 & 800 & 1000 & 500 & 0.05 & $-\$ 471,025.8$ \\
\hline 165 & 10 & 90 & 50 & 1.1 & 300 & 300 & 500 & 0.05 & $-\$ 432,803.2$ \\
\hline 166 & 4 & 50 & 50 & 1.8 & 800 & 1000 & 500 & 0.25 & $-\$ 429,888.6$ \\
\hline 167 & 4 & 90 & 50 & 1.1 & 300 & 300 & 500 & 0.25 & $-\$ 422,819.0$ \\
\hline 168 & 10 & 50 & 100 & 1.1 & 300 & 300 & 500 & 0.25 & $-\$ 394,540.6$ \\
\hline 169 & 4 & 50 & 100 & 1.1 & 300 & 300 & 150 & 0.25 & $-\$ 390,613.1$ \\
\hline 170 & 4 & 50 & 50 & 1.8 & 300 & 300 & 500 & 0.25 & $-\$ 359,192.6$ \\
\hline 171 & 4 & 50 & 50 & 1.8 & 800 & 1000 & 150 & 0.25 & $-\$ 319,917.1$ \\
\hline
\end{tabular}




\begin{tabular}{|c|c|c|c|c|c|c|c|c|c|}
\hline 172 & 4 & 90 & 50 & 1.1 & 300 & 300 & 150 & 0.25 & $-\$ 312,847.5$ \\
\hline 173 & 10 & 50 & 100 & 1.1 & 300 & 300 & 150 & 0.25 & $-\$ 284,569.1$ \\
\hline 174 & 4 & 50 & 50 & 1.8 & 300 & 300 & 150 & 0.25 & $-\$ 249,221.1$ \\
\hline 175 & 4 & 50 & 50 & 1.1 & 300 & 300 & 500 & 0.05 & $-\$ 241,690.3$ \\
\hline 176 & 10 & 50 & 50 & 1.8 & 800 & 1000 & 150 & 0.05 & $-\$ 233,196.4$ \\
\hline 177 & 10 & 50 & 50 & 1.8 & 800 & 1000 & 500 & 0.25 & $-\$ 217,800.7$ \\
\hline 178 & 10 & 90 & 50 & 1.1 & 300 & 300 & 500 & 0.25 & $-\$ 200,126.7$ \\
\hline 179 & 10 & 90 & 50 & 1.1 & 300 & 300 & 150 & 0.05 & $-\$ 194,973.8$ \\
\hline 180 & 4 & 50 & 50 & 1.1 & 300 & 300 & 500 & 0.25 & $-\$ 111,756.8$ \\
\hline 181 & 10 & 50 & 50 & 1.8 & 800 & 1000 & 150 & 0.25 & $-\$ 107,829.2$ \\
\hline 182 & 10 & 90 & 50 & 1.1 & 300 & 300 & 150 & 0.25 & $-\$ 90,155.2$ \\
\hline 183 & 10 & 50 & 50 & 1.8 & 300 & 300 & 500 & 0.05 & $-\$ 88,800.0$ \\
\hline 184 & 10 & 50 & 50 & 1.8 & 300 & 300 & 500 & 0.25 & $-\$ 41,060.8$ \\
\hline 185 & 4 & 50 & 50 & 1.1 & 300 & 300 & 150 & 0.05 & $-\$ 3,860.9$ \\
\hline 186 & 4 & 50 & 50 & 1.1 & 300 & 300 & 150 & 0.25 & $-\$ 1,785.3$ \\
\hline 187 & 10 & 50 & 50 & 1.8 & 300 & 300 & 150 & 0.25 & $\$ 68,910.7$ \\
\hline 188 & 10 & 50 & 50 & 1.8 & 300 & 300 & 150 & 0.05 & $\$ 149,029.5$ \\
\hline 189 & 4 & 90 & 100 & 1.1 & 800 & 300 & 500 & 0.25 & $\$ 291,210.2$ \\
\hline 190 & 4 & 50 & 50 & 1.1 & 800 & 1000 & 500 & 0.25 & $\$ 394,897.7$ \\
\hline 191 & 4 & 90 & 100 & 1.1 & 800 & 300 & 150 & 0.25 & $\$ 401,181.7$ \\
\hline 192 & 4 & 50 & 100 & 1.8 & 800 & 300 & 500 & 0.25 & $\$ 418,463.0$ \\
\hline 193 & 4 & 50 & 50 & 1.1 & 800 & 1000 & 150 & 0.25 & $\$ 504,869.2$ \\
\hline 194 & 4 & 50 & 100 & 1.8 & 800 & 300 & 150 & 0.25 & $\$ 528,434.5$ \\
\hline 195 & 4 & 90 & 50 & 1.8 & 800 & 300 & 500 & 0.25 & $\$ 545,715.7$ \\
\hline 196 & 10 & 50 & 50 & 1.1 & 300 & 300 & 500 & 0.25 & $\$ 577,528.9$ \\
\hline 197 & 4 & 90 & 100 & 1.1 & 800 & 300 & 500 & 0.05 & $\$ 629,784.7$ \\
\hline 198 & 4 & 90 & 50 & 1.8 & 800 & 300 & 150 & 0.25 & $\$ 655,687.2$ \\
\hline 199 & 10 & 50 & 50 & 1.1 & 300 & 300 & 150 & 0.25 & $\$ 687,500.4$ \\
\hline 200 & 4 & 50 & 50 & 1.1 & 800 & 1000 & 500 & 0.05 & $\$ 854,023.9$ \\
\hline 201 & 4 & 90 & 100 & 1.1 & 800 & 300 & 150 & 0.05 & $\$ 867,614.1$ \\
\hline 202 & 4 & 50 & 100 & 1.8 & 800 & 300 & 500 & 0.05 & $\$ 904,987.3$ \\
\hline 203 & 4 & 50 & 100 & 1.1 & 800 & 300 & 500 & 0.25 & $\$ 913,334.7$ \\
\hline 204 & 4 & 90 & 50 & 1.1 & 800 & 300 & 500 & 0.25 & $\$ 991,100.3$ \\
\hline 205 & 4 & 50 & 100 & 1.1 & 800 & 300 & 150 & 0.25 & $\$ 1,023,306.2$ \\
\hline 206 & 4 & 50 & 50 & 1.8 & 800 & 300 & 500 & 0.25 & $\$ 1,054,726.7$ \\
\hline 207 & 4 & 50 & 50 & 1.1 & 800 & 1000 & 150 & 0.05 & $\$ 1,091,853.3$ \\
\hline 208 & 4 & 90 & 50 & 1.1 & 800 & 300 & 150 & 0.25 & $\$ 1,101,071.8$ \\
\hline 209 & 4 & 50 & 100 & 1.8 & 800 & 300 & 150 & 0.05 & $\$ 1,142,816.8$ \\
\hline 210 & 4 & 50 & 50 & 1.8 & 800 & 300 & 150 & 0.25 & $\$ 1,164,698.2$ \\
\hline 211 & 4 & 90 & 50 & 1.8 & 800 & 300 & 500 & 0.05 & $\$ 1,180,190.0$ \\
\hline 212 & 10 & 50 & 50 & 1.1 & 300 & 300 & 500 & 0.05 & $\$ 1,248,990.6$ \\
\hline 213 & 4 & 50 & 50 & 1.1 & 800 & 300 & 500 & 0.25 & $\$ 1,302,162.5$ \\
\hline 214 & 4 & 50 & 50 & 1.1 & 800 & 300 & 150 & 0.25 & $\$ 1,412,134.0$ \\
\hline 215 & 4 & 90 & 50 & 1.8 & 800 & 300 & 150 & 0.05 & $\$ 1,418,019.4$ \\
\hline 216 & 10 & 50 & 50 & 1.1 & 300 & 300 & 150 & 0.05 & $\$ 1,486,820.1$ \\
\hline 217 & 10 & 90 & 100 & 1.1 & 800 & 300 & 500 & 0.25 & $\$ 1,584,946.4$ \\
\hline 218 & 10 & 90 & 100 & 1.1 & 800 & 300 & 150 & 0.25 & $\$ 1,694,917.9$ \\
\hline 219 & 10 & 50 & 50 & 1.1 & 800 & 1000 & 500 & 0.25 & $\$ 1,844,164.9$ \\
\hline
\end{tabular}




\begin{tabular}{|c|c|c|c|c|c|c|c|c|c|}
\hline 220 & 10 & 50 & 100 & 1.8 & 800 & 300 & 500 & 0.25 & $\$ 1,903,078.2$ \\
\hline 221 & 10 & 50 & 50 & 1.1 & 800 & 1000 & 150 & 0.25 & $\$ 1,954,136.4$ \\
\hline 222 & 4 & 50 & 100 & 1.1 & 800 & 300 & 500 & 0.05 & $\$ 1,975,219.8$ \\
\hline 223 & 10 & 50 & 100 & 1.8 & 800 & 300 & 150 & 0.25 & $\$ 2,013,049.7$ \\
\hline 224 & 4 & 90 & 50 & 1.1 & 800 & 300 & 500 & 0.05 & $\$ 2,143,399.2$ \\
\hline 225 & 4 & 50 & 100 & 1.1 & 800 & 300 & 150 & 0.05 & $\$ 2,213,049.2$ \\
\hline 226 & 10 & 90 & 50 & 1.8 & 800 & 300 & 500 & 0.25 & $\$ 2,221,210.1$ \\
\hline 227 & 4 & 50 & 50 & 1.8 & 800 & 300 & 500 & 0.05 & $\$ 2,281,000.5$ \\
\hline 228 & 10 & 90 & 50 & 1.8 & 800 & 300 & 150 & 0.25 & $\$ 2,331,181.6$ \\
\hline 229 & 4 & 90 & 50 & 1.1 & 800 & 300 & 150 & 0.05 & $\$ 2,381,228.6$ \\
\hline 230 & 4 & 50 & 50 & 1.8 & 800 & 300 & 150 & 0.05 & $\$ 2,518,829.9$ \\
\hline 231 & 4 & 50 & 50 & 1.1 & 800 & 300 & 500 & 0.05 & $\$ 2,816,116.7$ \\
\hline 232 & 4 & 50 & 50 & 1.1 & 800 & 300 & 150 & 0.05 & $\$ 3,053,946.2$ \\
\hline 233 & 10 & 50 & 100 & 1.1 & 800 & 300 & 500 & 0.25 & $\$ 3,140,257.6$ \\
\hline 234 & 10 & 50 & 100 & 1.1 & 800 & 300 & 150 & 0.25 & $\$ 3,250,229.1$ \\
\hline 235 & 10 & 90 & 50 & 1.1 & 800 & 300 & 500 & 0.25 & $\$ 3,334,671.5$ \\
\hline 236 & 10 & 90 & 100 & 1.1 & 800 & 300 & 500 & 0.05 & $\$ 3,427,678.1$ \\
\hline 237 & 10 & 90 & 50 & 1.1 & 800 & 300 & 150 & 0.25 & $\$ 3,444,643.0$ \\
\hline 238 & 10 & 50 & 50 & 1.8 & 800 & 300 & 500 & 0.25 & $\$ 3,493,737.5$ \\
\hline 239 & 10 & 50 & 50 & 1.8 & 800 & 300 & 150 & 0.25 & $\$ 3,603,709.0$ \\
\hline 240 & 10 & 90 & 100 & 1.1 & 800 & 300 & 150 & 0.05 & $\$ 3,665,507.6$ \\
\hline 241 & 10 & 50 & 50 & 1.1 & 800 & 1000 & 500 & 0.05 & $\$ 3,988,276.1$ \\
\hline 242 & 10 & 50 & 50 & 1.1 & 800 & 300 & 500 & 0.25 & $\$ 4,112,327.1$ \\
\hline 243 & 10 & 50 & 100 & 1.8 & 800 & 300 & 500 & 0.05 & $\$ 4,115,684.7$ \\
\hline 244 & 10 & 50 & 50 & 1.1 & 800 & 300 & 150 & 0.25 & $\$ 4,222,298.6$ \\
\hline 245 & 10 & 50 & 50 & 1.1 & 800 & 1000 & 150 & 0.05 & $\$ 4,226,105.5$ \\
\hline 246 & 10 & 50 & 100 & 1.8 & 800 & 300 & 150 & 0.05 & $\$ 4,353,514.2$ \\
\hline 247 & 10 & 90 & 50 & 1.8 & 800 & 300 & 500 & 0.05 & $\$ 4,803,691.3$ \\
\hline 248 & 10 & 90 & 50 & 1.8 & 800 & 300 & 150 & 0.05 & $\$ 5,041,520.7$ \\
\hline 249 & 10 & 50 & 100 & 1.1 & 800 & 300 & 500 & 0.05 & $\$ 6,791,265.9$ \\
\hline 250 & 10 & 50 & 100 & 1.1 & 800 & 300 & 150 & 0.05 & $\$ 7,029,095.3$ \\
\hline 251 & 10 & 90 & 50 & 1.1 & 800 & 300 & 500 & 0.05 & $\$ 7,211,714.3$ \\
\hline 252 & 10 & 90 & 50 & 1.1 & 800 & 300 & 150 & 0.05 & $\$ 7,449,543.8$ \\
\hline 253 & 10 & 50 & 50 & 1.8 & 800 & 300 & 500 & 0.05 & $\$ 7,555,717.6$ \\
\hline 254 & 10 & 50 & 50 & 1.8 & 800 & 300 & 150 & 0.05 & $\$ 7,793,547.1$ \\
\hline 255 & 10 & 50 & 50 & 1.1 & 800 & 300 & 500 & 0.05 & $\$ 8,893,508.2$ \\
\hline 256 & 10 & 50 & 50 & 1.1 & 800 & 300 & 150 & 0.05 & $\$ 9,131,337.6$ \\
\hline
\end{tabular}

